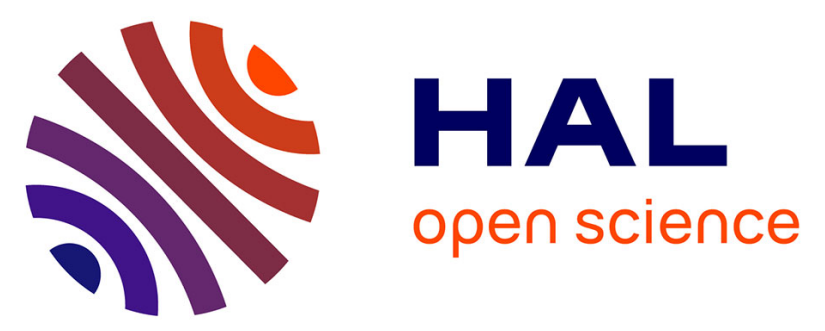

\title{
Curcumin-induced degradation of pkc( is associated with enhanced dentate ncam psa expression and spatial learning in adult and aged wistar rats.
}

Lisa Conboy, Andrew G. Foley, Noel M. O’Boyle, Marie Lawlor, Helen C. Gallagher, Keith J. Murphy, Ciaran M. Regan

\section{To cite this version:}

Lisa Conboy, Andrew G. Foley, Noel M. O'Boyle, Marie Lawlor, Helen C. Gallagher, et al.. Curcumininduced degradation of pkc( is associated with enhanced dentate ncam psa expression and spatial learning in adult and aged wistar rats.. Biochemical Pharmacology, 2009, 77 (7), pp.1254. 10.1016/j.bcp.2008.12.011 . hal-00493480

\section{HAL Id: hal-00493480 \\ https://hal.science/hal-00493480}

Submitted on 19 Jun 2010

HAL is a multi-disciplinary open access archive for the deposit and dissemination of scientific research documents, whether they are published or not. The documents may come from teaching and research institutions in France or abroad, or from public or private research centers.
L'archive ouverte pluridisciplinaire HAL, est destinée au dépôt et à la diffusion de documents scientifiques de niveau recherche, publiés ou non, émanant des établissements d'enseignement et de recherche français ou étrangers, des laboratoires publics ou privés. 


\section{Accepted Manuscript}

Title: Curcumin-induced degradation of pkc(is associated with enhanced dentate ncam psa expression and spatial learning in adult and aged wistar rats.

Authors: Lisa Conboy, Andrew G. Foley, Noel M. O'Boyle, Marie Lawlor, Helen C. Gallagher, Keith J. Murphy, Ciaran

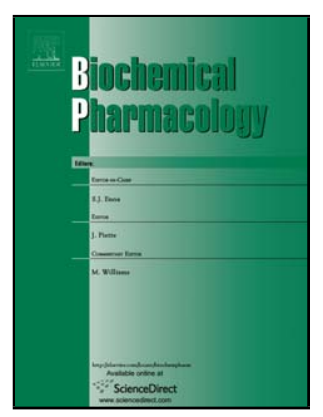

M. Regan

PII: S0006-2952(08)00909-X

DOI:

Reference: doi:10.1016/j.bcp.2008.12.011 BCP 10054

To appear in: $\quad B C P$

Received date: $\quad 7-11-2008$

Revised date: $\quad$ 19-12-2008

Accepted date: $\quad$ 19-12-2008

Please cite this article as: Conboy L, Foley AG, O'Boyle NM, Lawlor M, Gallagher $\mathrm{HC}$, Murphy KJ, Regan CM, Curcumin-induced degradation of pkc( is associated with enhanced dentate ncam psa expression and spatial learning in adult and aged wistar rats., Biochemical Pharmacology (2008), doi:10.1016/j.bcp.2008.12.011

This is a PDF file of an unedited manuscript that has been accepted for publication. As a service to our customers we are providing this early version of the manuscript. The manuscript will undergo copyediting, typesetting, and review of the resulting proof before it is published in its final form. Please note that during the production process errors may be discovered which could affect the content, and all legal disclaimers that apply to the journal pertain. 


\section{CURCUMIN-INDUCED DEGRADATION OF PKC $\delta$ IS ASSOCIATED WITH \\ ENHANCED DENTATE NCAM PSA EXPRESSION AND SPATIAL LEARNING IN ADULT AND AGED WISTAR RATS.}

Lisa Conboy, Andrew G. Foley, Noel M. O’Boyle, Marie Lawlor, Helen C. Gallagher, Keith J. Murphy and Ciaran M. Regan.

School of Biomolecular and Biomedical Sciences, UCD Conway Institute, University College Dublin, Belfield, Dublin 4, IRELAND.

Corresponding author:

Prof. Ciaran Regan

UCD Conway Institute

University College Dublin

Belfield, Dublin 4, IRELAND.

Tel: $+353-1-7166775$

Fax: +353-1-7166920

E-mail:ciaran.regan@ucd.ie 


\begin{abstract}
ABBREVIATIONS: DMEM: Dulbecco's modified Eagle's medium; NCAM: neural cell adhesion molecule; PKC: protein kinase C; PSA: Poly- $\alpha 2,8$-linked sialic acid; PST: polysialyltransferase; curcumin (diferuloylmethane; 1,7-bis-[4-hydroxy-3-methoxyphenyl]-1,6heptadiene-3,5-dione) and rottlerin (mallotoxin; 5,7-dihydroxy-2,2-dimethyl-6-[2,4,6-trihydroxy3-methyl-5-acetylbenzyl]-8-cinnamoyl-1,2-chromine).
\end{abstract}




\begin{abstract}
Polysialylation of the neural cell adhesion molecule (NCAM PSA) is necessary for the consolidation processes of hippocampus-based learning. Previously, we have found inhibition of protein kinase $\mathrm{C}$ delta $(\mathrm{PKC} \delta$ ) to be associated with increased polysialyltransferase activity (PST), suggesting inhibitors of this kinase might ameliorate cognitive deficits. Using a rottlerin template, a drug previously considered an inhibitor of $\mathrm{PKC} \delta$, we searched the CAP database with the Accelrys ${ }^{\circledR}$ Catalyst programme for structurally similar molecules and, using the available crystal structure of the phorbol-binding domain of $\mathrm{PKC} \delta$, found that diferuloylmethane (curcumin) docked effectively into the phorbol site. Curcumin increased NCAM PSA expression in cultured neuro-2A neuroblastoma cells and this was inversely related to $\mathrm{PKC} \delta$ protein expression. Curcumin did not directly inhibit PKC $\delta$ activity but formed a tight complex with the enzyme. With increasing doses of curcumin, the $\operatorname{Tyr}^{131}$ residue of $\mathrm{PKC} \delta$, which is known to direct its degradation, became progressively phosphorylated and this was associated with numerous $\mathrm{Tyr}^{131}$-phospho-PKC $\delta$ fragments. Chronic administration of curcumin in vivo also increased the frequency of polysialylated cells in the dentate infragranular zone and significantly improved the acquisition and consolidation of a water maze spatial learning paradigm in both adult and aged cohorts of Wistar rats. These results further confirm the role of PKC $\delta$ in regulating PST and NCAM PSA expression and provide evidence that drug modulation of this system enhances the process of memory consolidation.
\end{abstract}

RUNNING TITLE: PKC $\delta$ degradation enhances NCAM PSA and cognition.

KEY WORDS: PKC $\delta$; PST; NCAM PSA; curcumin; spatial learning. 


\section{INTRODUCTION}

A significant post-translational modification of the neural cell adhesion molecule (NCAM) involves the attachment of large homopolymers of $\alpha 2,8$-linked polysialic acid (PSA), a modification that is specific to NCAM in the mammalian brain [1] and [2]. This posttranslational modification of NCAM has been extensively argued to support structural plasticity in the adult nervous system [3], [4] and [5] and has been implicated in activity-dependent synaptic remodelling [6] and [7]. Moreover, the synaptic remodeling that accompanies task consolidation of spatial learning and avoidance conditioning paradigms [8], [9] and [10] is associated with a transient increase in the frequency of dentate granule cells expressing polysialylated NCAM at the $12 \mathrm{~h}$ post-training time [11], [12] and [13] and cleavage of PSA with endoneuraminidase-N impairs the development of long-term potentiation (LTP), a cellular analogue of memory and learning, and the consolidation of spatial learning and avoidance conditioning paradigms [14], [15], [16] and [17]. Intraventricular infusion of anti-PSA, when administered specifically at the $10 \mathrm{~h}$ post-training time, has also been demonstrated to impair the consolidation of spatial and avoidance conditioning tasks, further confirming the time-dependent functional requirement of NCAM PSA in memory formation [18]. Polysialylation of NCAM occurs in the trans-Golgi compartment and is catalyzed by two enzymes termed sialyltransferaseX (STX or ST8SiaII) [19] and [20] and polysialyltransferase (PST or ST8SiaIV) [21] and [22]. These two polysialyltransferases regulate NCAM polysialylation state differentially during development as STX is the dominant $\alpha 2,8$-polysialyltransferase in the embryonic and early postnatal period whereas PST is mainly associated with $\alpha 2,8$-polysialylation in the postnatal 
brain [23] and [24]. Pulse-labelling studies in vitro have indicated PSA synthesis to occur in the late-Golgi, or post-Golgi, compartment where NCAM becomes rapidly glycosylated with the newly synthesized $\alpha 2,8$-polysialic acid [25].

In general, the molecular events associated with regulation of sialyltransferase-mediated glycosylation events still remain to be fully elucidated. The proposed involvement of PKC in the regulation of PST-mediated NCAM polysialylation state stems from the observation that phorbol-12-myristate-13-acetate, which activates diacylglycerol-dependent PKC isoforms, induces a dose-dependent decrease in NCAM PSA expression in neuro-2A neuroblastoma cells and staurosporine, a pan-specific PKC inhibitor, increases NCAM polysialylation state [26] Moreover, immunoblotting procedures have demonstrated reduced PKC $\delta$ expression to be associated with the enhanced polysialylation of NCAM in vitro and, using a polyclonal antibody directed against a conserved 11-amino acid sequence in E. coli polysialyltransferase, hippocampal PKC $\delta$ has been found to form complexes with PST that increase as animals age [27] and NCAM PSA expression decreases in an exponential manner [28]. The PST associated with these complexes has also been observed to be phosphorylated on serine residues [27], a mechanism known to be associated with the inhibition of other sialyltransferases [29], [30], [31] and [32]. Phosphorylated tyrosine residues on PST are also found in PST:PKC $\delta$ immunocomplexes [27] and this may play a crucial role in regulating $\mathrm{PKC} \delta$ expression as phosphorylation of conserved tyrosine residues in the hinged bilobal structure, typical of the PKC family of isozymes, confers a specific post-translational control on the rate of proteolytic cleavage [33] and [34]. 
In previous studies directed to providing evidence for a role of $\mathrm{PKC} \delta$ in the regulation of NCAM polysialylation in neuro-2A neuroblastoma cells [26], we employed rottlerin to inhibit $\mathrm{PKC} \delta$, as this had been reported to have an $\mathrm{IC}_{50}$ value of $3-6 \mathrm{uM}$ and to be 5-17 times more potent as a PKCס inhibitor over other PKC isozymes [35]. Neuro-2A cells exposed to rottlerin $(5 \mu \mathrm{M})$ in the mid-log growth phase, when NCAM PSA expression is dominant, resulted in a rapid and substantial increase in NCAM polysialylation state [26]. Moreover, exposure of the same concentration of rottlerin to cells in contact inhibition, where no NCAM PSA is expressed, resulted in PST activation and expression of polysialylated NCAM. Subsequent studies, however, have failed to confirm rottlerin to be a direct inhibitor of PKC $\delta$ [36] but that it may modulate the tyrosine phosphorylation state of $\mathrm{PKC} \delta$ and indirectly affect enzyme activity [37]. We now demonstrate curcumin to be a chemical similar of rottlerin that indirectly modulates PKC $\delta$ activity by modifying its phosphorylation state to increase the rate of degradation. 


\section{MATERIALS AND METHODS}

\subsection{Materials}

All routine laboratory chemicals, secondary antibodies, rottlerin, staurosporine and curcumin were purchased from Sigma-Aldrich, Ireland. All components of the PKC $\delta$ activity assay, including constitutively active recombinant $\mathrm{PKC} \delta$, were purchased from Upstate Biotechnology (Charlottesville, VA). $\left[\gamma^{32} \mathrm{P}\right]$-ATP was purchased from Amersham Biosciences (Buckinghamshire, UK). The BCA assay was purchased from Pierce (Rockford, IL). The monoclonal antibody raised against the meningococcus group B polysaccharides (anti-PSA) was a kind gift of Prof. G. Rougon [2]. Monoclonal primary antibody to PKC $\delta$ was purchased from BD Biosciences (Oxford, UK).

\subsection{In silico studies}

Database searching with Catalyst and protein-ligand docking with Cerius2

Computational studies were carried out using a Silicon Graphics Octane workstation (SGI, Mountain View, CA). Catalyst version 3.4 (Accelrys, Cambridge, UK) was used to search the Compounds Available for Purchase (CAP) database to identify those structurally similar to rottlerin using a template structure based on its side chain (see Figure 1A). Prior to database screening, the search was restricted to drug-like molecules based on the Lipinski rules [38]. Using Cerius2 (version 4.8, Accelrys, UK), the matching compounds were rated using proteinligand docking to the crystal structure of the PKC $\delta$ ligand binding domain which was downloaded from the Brookhaven Protein Data Bank. In preparation for docking, all organic and 
inorganic cofactors, the phorbol ester ligand, as well as all water molecules, were removed from the PKC $\delta$ crystal structure. Potential PKC $\delta$ inhibitors were sequentially docked to the PKC $\delta$ crystal structure and ligand-enzyme interactions were quantified using the DOCK scoring function of the LigFit module of Cerius2. The top ranking compounds were screened in in vitro assays, described below, to determine their potential to modulate NCAM-PSA.

\subsection{In vitro analysis of NCAM PSA expression}

The mouse neuroblastoma cell line, neuro-2A, was maintained in Dulbecco's modified Eagle's medium (DMEM; Gibco, UK) supplemented with 10\% (v/v) foetal calf serum (Gibco, UK) and penicillin/streptomycin $\left(100 \mathrm{mg} / \mathrm{ml}\right.$; Sigma, UK) at $37{ }^{\circ} \mathrm{C}$ in a humidified atmosphere and $9 \%$ $\mathrm{CO}_{2}$. To investigate pharmacological modulation of PSA expression, cells were seeded on 96well plates at a density of $10^{4}$ cells $/ \mathrm{cm}^{2}$ and grown until day 3 in vitro (DIV 3). On DIV3, cells were treated with either vehicle (DMSO not exceeding $1 \% \mathrm{v} / \mathrm{v}$ ) or test PKC $\delta$ inhibitor ranging in dose from $1 \mu \mathrm{M}$ to $500 \mu \mathrm{M}$ for 5 hours. Specifically, curcumin was administered at concentrations of 1,10,50,100 and $500 \mu \mathrm{M}$. Cells were then fixed with $200 \mu \mathrm{l}$ of $4 \%$ paraformaldehyde in DMEM for $60 \mathrm{~min}$ at room temperature. This was replaced with undiluted fixative for a further $60 \mathrm{~min}$. Non-specific binding sites were blocked with $2 \%(\mathrm{w} / \mathrm{v})$ bovine serum albumin (Sigma-Aldrich, Ireland) and 2\% (v/v) normal goat serum (Sigma-Aldrich, Ireland) in PBS (blocking solution; in which all antibodies were also diluted). PSA was detected using a monoclonal antibody raised against the meningococcus group B polysaccharides (antiPSA) prepared as an ascitic fluid and diluted 1:500. Primary antibody was incubated overnight at $4{ }^{\circ} \mathrm{C}$. Binding of the primary antibody was detected using a secondary goat anti-mouse $\operatorname{IgG}$ conjugated to peroxidase diluted 1:2000 for 1 hour at room temperature. Peroxidase activity was 
determined using the liquid substrate tetramethylbenzidine (Sigma-Aldrich, Ireland), which was incubated for $30 \mathrm{~min}$ at room temperature and the reaction was terminated by acidification with 2 $\mathrm{M} \mathrm{H}_{2} \mathrm{SO}_{4}$. Optical density was measured in a microplate reader with a $450 \mathrm{~nm}$ measurement filter and $620 \mathrm{~nm}$ reference filter.

\subsection{PKC $\delta$ activity assay}

Constitutively active recombinant $\mathrm{PKC} \delta$ was derived from Sf21 cells and assay of enzyme activity was performed according to the manufacture's instructions. In brief, 0-20 ng of recombinant PKC $\delta$ was incubated with $50 \mu \mathrm{M}$ PKC substrate peptide (myelin basic protein), in the presence of $200 \mu \mathrm{M}$ ATP, $30 \mathrm{mM}$ magnesium chloride, $0.05 \mathrm{mg} / \mathrm{ml}$ phosphatidylserine, 0.005 $\mathrm{mg} / \mathrm{ml}$ diacylglycerol and $\left[\gamma_{-}{ }^{32} \mathrm{P}\right]$-ATP (Amersham Biosciences, UK) for $10 \mathrm{~min}$ at $30{ }^{\circ} \mathrm{C}$. Following incubation $20 \mu \mathrm{l}$ of each assay was spotted onto phosphocellulose paper and the reaction terminated by washing of the phosphocellulose in $0.75 \%$ phosphoric acid for 5 minutes. Following two subsequent 5 minute washes in phosphoric acid, the samples were washed in acetone for a further $5 \mathrm{~min}$. The phosphocellulose paper was dried, transferred to scintillation fluid and the radioactivity counted. Under these conditions, increasing concentrations of PKC $\delta$ were associated with increasing levels of radioactivity. Using $20 \mathrm{ng}$ of recombinant $\mathrm{PKC} \delta$ and the conditions described above, staurosporine $(5 \mathrm{nM})$, rottlerin $(10 \mu \mathrm{M}$ and $100 \mu \mathrm{M})$ and curcumin $(10 \mu \mathrm{M}$ and $500 \mu \mathrm{M})$ were included in the assay and their ability to inhibit PKC $\delta$ kinase activity in a dose-dependent manner was determined. In additional experiments, the assay concentration of ATP was lowered to $40 \mu \mathrm{M}$ ATP to determine potential competition at the ATP binding site. 


\subsection{Immobilisation of curcumin on Epoxy-activated Sepharose 6B}

To investigate curcumin-PKC $\delta$ interactions, curcumin was coupled to epoxy-activated Sepharose $^{\mathrm{TM}}$ 6B (Sigma-Aldrich, Ireland). Using a method adapted from [39] a 1 gm aliquot of epoxy-activated Sepharose $6 \mathrm{~B}$ beads was washed in $50 \mathrm{ml}$ of $\mathrm{dH}_{2} \mathrm{O}$ for 5 cycles to give approximately $3.5 \mathrm{ml}$ of swollen beads. For coupling to the epoxy-activated beads, curcumin was prepared as a $20 \mathrm{mM}$ solution in $50 \%$ dimethylformamide $/ 0.1 \mathrm{M} \mathrm{Na}_{2} \mathrm{CO}_{3} / 10 \mathrm{mM} \mathrm{NaOH}$ and two volumes of this solution was mixed with one volume of swollen beads and incubated overnight at $30{ }^{\circ} \mathrm{C}$ in the dark. The following day, the curcumin-Sepharose suspension was washed 3 times with coupling buffer and the remaining non-specific binding sites were blocked by incubation with $1 \mathrm{M}$ ethanolamine overnight at $30^{\circ} \mathrm{C}$. Control beads were prepared by incubating the epoxy-activated Sepharose 6B with $1 \mathrm{M}$ ethanolamine, $\mathrm{pH} 11$. The control and curcumin-coupled beads were finally washed in 3 cycles of alternating low $(0.1 \mathrm{M}$ acetate buffer, $\mathrm{pH} 4.0$ ) and high (0.1M Tris-HCl buffer, $\mathrm{pH} 8$, containing $0.5 \mathrm{M} \mathrm{NaCl}) \mathrm{pH}$ buffers. Hippocampal PKC $\delta$ was prepared by homogenising rat dentate gyrus in $100 \mathrm{mM}$ Hepes buffer, pH 7.6, containing $300 \mathrm{mM} \mathrm{NaCl}, 1 \%$ Triton-X-100, 2 mM EDTA, 2 mM EGTA and $0.1 \mathrm{mM}$ PMSF, $50 \mathrm{mM} \mathrm{Na}_{3} \mathrm{VO}_{4}$ and $1 \mu \mathrm{g} / \mu \mathrm{l}$ aprotinin as protease inhibitors (2X lysis buffer). A $250 \mu \mathrm{l}$ aliquot of cell lysate was incubated with $20 \mu \mathrm{l}$ of curcumin-coupled Sepharose, or control beads, with constant mixing for $3 \mathrm{~h}$ at $4{ }^{\circ} \mathrm{C}$. Afterwards, the curcumin-Sepharose complex was washed twice with $500 \mu \mathrm{l}$ of $2 \mathrm{X}$ lysis buffer (without protease inhibitor) containing $150 \mathrm{mM} \mathrm{NaCl}$ (low salt) followed by $500 \mu \mathrm{l}$ of $1 \mathrm{X}$ lysis buffer containing $1 \mathrm{M} \mathrm{NaCl}$ (high salt). Proteins were 
isolated from the bead-protein complex by resuspending and boiling the washed beads in SDSPAGE sample buffer. PKC $\delta$ was detected by the immunoblotting procedure described below.

\subsection{Immunoblot analysis of PKC $\delta$ expression}

Neuro-2A cells were seeded in $75 \mathrm{~cm}^{2}$ plates $\left(10^{4}\right.$ cells $\left./ \mathrm{cm}^{2}\right)$ and exposed to increasing concentrations of curcumin for $5 \mathrm{~h}$ during the mid-log growth phase, as described above. The cells were then washed 3 times in phosphate-buffered saline, scraped and pelleted by centrifugation for $10 \mathrm{~min}$ at $900 \mathrm{rpm}$. The pellet was solubilised in RIPA buffer (50 mM Tris, $\mathrm{pH}$ 8.0, containing $50 \mathrm{mM} \mathrm{NaCl}, 1.0 \% \mathrm{NP}-40,0.5 \%$ sodium deoxycholate, and $0.1 \% \mathrm{SDS}$,) containing protease inhibitors for $30 \mathrm{~min}$ on ice. The supernatant was then collected by centrifugation at $3000 \mathrm{~g}$ and the protein concentrations determined by the BCA assay. Samples, of equal protein concentration, were boiled for $10 \mathrm{~min}$ in a reducing sample buffer of $70 \mathrm{mM}$ Tris-HCl, pH 6.8, containing $33 \mathrm{mM} \mathrm{NaCl}, 1 \mathrm{mM}$ EDTA, 2\% (w/v) SDS, $0.01 \%$ (w/v) bromophenol blue, 10\% glycerol and 3\% (v/v) dithiothreitol reducing agent (New England Biolabs, UK). Samples containing equal amounts of protein were separated on $10 \%$ polyacrylamide minigels and electrophoretically transferred to nitrocellulose membranes and successful transfer was confirmed by ponceau S staining of the membrane (not shown). The nitrocellulose was then blocked using washing buffer $(10 \mathrm{mM}$ Tris-HCl, $\mathrm{pH}$ 7.4, containing 150 $\mathrm{mM} \mathrm{NaCl}$, and $0.05 \%[\mathrm{v} / \mathrm{v}]$ Tween-20) with $5 \%(\mathrm{w} / \mathrm{v})$ non-fat milk powder for $1 \mathrm{~h}$ at room temperature. The monoclonal primary antibody to $\mathrm{PKC} \delta$ was diluted 1:1000 in blocking buffer and incubated overnight at $4{ }^{\circ} \mathrm{C}$ with the nitrocellulose membrane. The primary antibody was then detected using goat anti-mouse IgG peroxidase conjugated secondary antibody. Following membrane washing, the immuno-complexes were detected using a chemiluminescence 
peroxidase substrate and exposure of the membranes to x-ray film (Kodak, Dublin, Ireland). Equal protein loading was verified by stripping the blots and re-probing them with an anti-actin monoclonal antibody (Sigma-Aldrich, Ireland) diluted 1: 20000. The developed x-ray films were scanned using Adobe Photoshop 7.0.

\subsection{Quantitative immunohistochemical analysis of NCAM PSA in vivo}

Male Wistar rats (postnatal day 80) were obtained from the Biomedical Facility, University College Dublin, and housed singly in a $12 \mathrm{~h}$ light/dark cycle at $22 \pm 2{ }^{\circ} \mathrm{C}$, with ad libitum access to food and water. Curcumin $(75 \mathrm{mg} / \mathrm{kg})$, dissolved in a methylcellulose $(0.5 \% \mathrm{w} / \mathrm{v})$ vehicle, was administered daily by gavage for an 8-day period. Control animals received the methylcellulose vehicle for the same 8-day period. At $24 \mathrm{~h}$ after the final drug administration, the animals were sacrificed by cervical dislocation and the whole brain was quickly dissected. The brains were coated immediately in an optimal cutting temperature compound (Gurr, Poole, UK), snap-frozen in $\mathrm{CO}_{2}$-cooled $\mathrm{n}$-hexane, and stored at $-80^{\circ} \mathrm{C}$ until required for further processing. The frequency of hippocampal polysialylated neurons was determined using PSA immunohistochemistry, as described previously [11]. Briefly, cryostat axial sections of $12 \mu \mathrm{m}$ sections were fixed in $70 \%$ (v/v) ethanol and incubated overnight with anti-PSA ascitic fluid diluted 1:500 in phosphate buffered saline (PBS). The sections were exposed for $3 \mathrm{~h}$ to fluorescein-conjugated goat antimouse IgM diluted 1:100 in PBS and mounted in Citifluor (Citifluor Ltd., UK), a fluorescenceenhancing medium. The total numbers of PSA-immunopositive neurons at the infragranular cell layer of the dentate gyrus, at $-5.6 \mathrm{~mm}$ with respect to bregma, were counted in seven alternate $12 \mu \mathrm{m}$ sections. The sections were counter-stained with propidium iodide (60 s; $40 \mathrm{ng} / \mathrm{ml})$

(Sigma-Aldrich, Ireland) to facilitate cell identification and the use of alternate sections precluded 
double counting of the 5-10 $\mu$ m perikarya. Cell counts were expressed per unit area of the dentate granule cell layer $\left(0.15 \mathrm{~mm}^{2}\right)$ and the mean \pm SEM for each treatment group calculated.

\subsection{Water maze spatial learning paradigm}

Separate cohorts of male Wistar rats (postnatal day 80 and postnatal day 540), sourced and maintained as described above, were used in these studies. On each of the 2 days preceding commencement of water maze studies, animals were handled and assessed in an open field arena for locomotor activity, rearing and general behaviour over a 5 min period. Each cohort of animals was treated for 8 days with $75 \mathrm{mg} / \mathrm{kg}$ curcumin by gavage. An extended 40 -day treatment period did not confer any additional advantage on the parameters under investigation (data not shown). The control groups received vehicle alone. Water maze training was initiated at $24 \mathrm{~h}$ following the final drug administration. The water maze apparatus consisted of a large circular pool $\left(1 \mathrm{~m}\right.$ diameter, $80 \mathrm{~cm}$ high, water temperature $\left.26 \pm 1{ }^{\circ} \mathrm{C}\right)$ with a platform $(11 \mathrm{~cm}$ diameter) submerged $1.5 \mathrm{~cm}$ below the water surface [12]. The water was $50 \mathrm{~cm}$ deep and the wall of the pool was $30 \mathrm{~cm}$ above the level of the water. Both the pool and the platform were constructed of black polyvinyl plastic and offered no intra-maze cues to guide escape behaviour. The experimental room contained several extra-maze visual cues. During testing the platform was hidden in the same quadrant $30 \mathrm{~cm}$ from the side wall. Animals were trained in 4 training sessions separated by $24 \mathrm{~h}$ and each session, consisting of 5 trials, was separated by an inter-trial test interval of $300 \mathrm{~s}$. Each trial started with the rat facing the wall of the maze at one of three fixed points $\mathrm{A}, \mathrm{B}$, or $\mathrm{C}$ arranged triangularly around the pool (separated by $120^{\circ}$ ). The starting positions were used sequentially over the five trials of each training session and continuity in the 
pattern of starting positions was maintained over different sessions so that all starting points were used the same number of times. Computerised tracking software (Watermaze 3.1) was used to measure relevant parameters that included swim angle, swim speed, escape latency and path length. The time taken by the rat to find the hidden platform within a $60 \mathrm{~s}$ criterion period was defined as the escape latency time. On the first trial, rats failing to locate the platform within the $60 \mathrm{~s}$ period were placed on it for $10 \mathrm{~s}$. Escape latencies were measured over 5 trials in each training session. Probe trials were performed at 1 and 3 days following the final training session. In these trials the platform was removed and the time spent in each quadrant of the pool was tracked over a $60 \mathrm{~s}$ period.

\begin{abstract}
All experimental procedures were approved by the Animal Research Ethics Committee of University College Dublin and were carried out by individuals holding the appropriate national license issued by the Department of Health.
\end{abstract}

\title{
2.9 Statistics
}

All statistical analysis was carried out using GraphPad Prism (version 4) software. Curcumin effects on NCAM-PSA and PKC $\delta$ expression were analysed by using Student's unpaired twotailed $t$-test. Kinase activity assay values were analysed by ANOVA followed by Dunnett's posthoc analysis. The effect of drug treatment and trial number on escape latency from the water maze was assessed by repeated measures ANOVA. Specific trials and probe differences were analysed using Student's unpaired two-tailed $t$-test. In all cases, $P$ values less than 0.05 were considered to be significant. 


\section{RESULTS}

\subsection{Identification of curcumin as a chemical similar of rottlerin}

Taking rottlerin as our template structure, we used the substructure highlighted in bold in Figure 1A to search the CAP database for structurally similar chemicals using the Accelrys ${ }^{\circledR}$ Catalyst programme. This allowed the identification of 137 compounds. This list of compounds was further refined using the Accelrys ${ }^{\circledR}$ Cerius2 modelling and simulation program to test for ligand fit to the crystallised $\mathrm{C} 1 \mathrm{~B}$ phorbol-binding domain of the $\mathrm{PKC} \delta$ molecule (Figure 1Bi). The C1B domain of the regulatory region of $\mathrm{PKC} \delta$, containing the phorbol ester, was obtained from the Protein Data Base (PKC $\delta$ C1B domain RCSB PDB entry 1PTQ; [40]; Figure 1Bii). The phorbol ester was removed and the binding site defined using the site search function of Cerius2. The energy of the PKC $\delta$ crystal structure was minimised using the Dreiding 2.21 force field and energy minimised rottlerin conformers were docked to the PKC $\delta$ phorbol-binding site. The ligand-enzyme score was quantified using the 'DOCK' score of the Cerius2 LigFit module, which rated interaction energy and internal ligand energy between enzyme and ligand. DOCK scores of the 137 identified compounds with the $\mathrm{PKC} \delta \mathrm{C} 1 \mathrm{~B}$ phorbol-binding domain showed a normal distribution (Figure 1C). Within this distribution, both curcumin and rottlerin exhibited high DOCK scores of 92 and 87, respectively, indicating significant chemical similarity between these compounds. The interaction of curcumin with the $\mathrm{PKC} \delta \mathrm{C} 1 \mathrm{~B}$ phorbol-binding domain is illustrated in Figure 1Biii. Using an ELISA based assay, curcumin was also found to enhance NCAM PSA expression in a dose-dependent manner in neuro-2A neuroblastoma cells (Figure 1D). This confirmed curcumin to have the same biological activity of rottlerin, as reported previously [26], and that both compounds most likely influenced PKC $\delta$ activity in a similar 
manner. The dose of curcumin required to enhance NCAM PSA expression was, however, an order of magnitude greater than that previously reported for rottlerin (5 $\mu \mathrm{M}$; [26]. This difference in dose-response is most likely related to the unstable nature of curcumin at neutral and basic $\mathrm{pH}$ both of which lead to its rapid degradation and formation of ferulic acid, a potent antioxidant [41]. Ferulic acid, however, failed to enhance NCAM PSA expression in the neuro-2A neuroblastoma cell line (data not shown) further confirming the primary role of curcumin in this effect.

\subsection{Influence of curcumin and rottlerin on PKC $\delta$ kinase activity.}

Given that previous studies demonstrated rottlerin to be without effect on PKC $\delta$ activity [36] and [37], we determined if curcumin similarly failed to influence enzyme activity. The in vitro assay employed determined the influence of curcumin on the phosphorylation rate of myelin basic protein using purified human recombinant $\mathrm{PKC} \delta$ protein (Figure $2 \mathrm{~A}$ ) in the presence of $\left[\gamma_{-}{ }^{32} \mathrm{P}\right]-$ ATP and phosphatidylserine and DAG lipid activators. Using this assay, the phosphorylation rate of myelin basic protein substrate was found to be directly related to the concentration of PKC $\delta$ enzyme present (Figure 2B). We further validated the assay using the non-specific PKC inhibitor staurosporine and found it to inhibit PKC $\delta$ kinase activity in a dose-dependent manner (data not shown). Staurosporine exhibited an $\mathrm{IC}_{50}$ value of approximately $5 \mathrm{nM}$ which is in close agreement with the $\mathrm{IC}_{50}$ value of $3.5 \mathrm{nM}$ reported previously [42]. At $5 \mathrm{nM}$, staurosporine reduced PKC $\delta$ kinase activity to $47.3 \pm 9.2 \%$ of that observed in the control sample (Figure $2 \mathrm{C}$ ). In comparison to rottlerin and curcumin, over concentration ranges of $10-100 \mu \mathrm{M}$ or $100-500 \mu \mathrm{M}$, respectively, only staurosporine inhibited $\mathrm{PKC} \delta$ activity $(\mathrm{F}[5,12]=11.09 ; P<0.05)$. To further preclude the possibility that rottlerin or curcumin may be acting as competitive inhibitors at the 
PKC $\delta$ ATP binding site, we determined the consequence of lowering available ATP ( $200 \mathrm{uM}$ to $40 \mu \mathrm{M})$ on kinase activity. At this lower ATP concentration, staurosporine further reduced PKC $\delta$ kinase activity to $29.5 \pm 8.4 \%$ of the control value but it was without effect on the ability of curcumin or rottlerin to inhibit PKC $\delta$ activity (Figure 2C). These results demonstrated rottlerin to be without any direct effect on $\mathrm{PKC} \delta$ activity, confirming previous reports [36], and that the related compound curcumin similarly failed to influence enzyme activity.

\subsection{Curcumin binding promotes PKC $\delta$ degradation.}

Given curcumin failed to inhibit PKC $\delta$ activity, despite its high DOCK score for the phorbolbinding site of the enzyme, we determined if curcumin formed a complex with the enzyme. To achieve this, we covalently coupled curcumin to epoxy-activated Sepharose 6B, via its available hydroxyl groups, and used these beads to bait PKC $\delta$ in lysates of rat dentate gyrus solubilised with a non-ionic detergent, a procedure employed previously to identify the cellular targets of other protein kinase inhibitors [39]. Incubation of the dentate lysate with curcumin-coupled Sepharose resulted in PKC $\delta$ forming a tight linkage to curcumin. Following removal of weaklybound proteins by a cycle of low- and high-salt wash and rigorous boiling in SDS gel sample buffer, the remaining Coomassie blue-stained electrophoretic protein profile was found to be comparable across all treatment conditions (Figure 3A; equal protein loading). Immunoblot analysis with anti-PKC $\delta$, however, revealed the enzyme to be associated with the curcumincoupled Sepharose 6B and not with the control Sepharose 6B (Figure 3B; lanes 1 and 2). Moreover, the curcumin-coupled Sepharose 6B bound all of the PKC $\delta$ in the lysate as immunoblot analysis of the remainder failed to detect any enzyme immunoreactivity (Figure 3B; lane 4) and this was in contrast to the abundant $\mathrm{PKC} \delta$ immunoreactivity observed in the lysate 
following incubation with the control Sepharose 6B (Figure 3B; lane 5). Moreover, the tight association of PKC $\delta$ with curcumin appeared to exert an allosteric effect that rendered the enzyme more amenable to $\mathrm{Tyr}^{311}$ phosphorylation. Exposure of the neuro-2A neuroblastoma cell line to curcumin for a $5 \mathrm{~h}$ period resulted in a dose-dependent decrease in $\mathrm{PKC} \delta$ protein expression with no effect being observed on actin protein levels (Figure 4A and B). This increase in $\mathrm{PKC} \delta$ protein degradation was paralleled by a dose-dependent increase in the phosphorylation of the $\mathrm{Tyr}^{311}$ residue of $\mathrm{PKC} \delta$, accompanied by $\mathrm{Tyr}^{311}$ phosphorylated enzyme protein fragments (Figure 4C), suggesting the association of curcumin with $\mathrm{PKC} \delta$ directed its degradation which is in agreement with previous work relating $\mathrm{PKC} \delta \mathrm{Tyr}^{311}$ phosphorylation to its increased proteolysis [34].

\subsection{Curcumin enhances NCAM polysialylation state and spatial learning in adult Wistar} rats.

Given the transient increase in polysialylated neurons in the hippocampal formation that accompanies consolidation of an avoidance conditioning paradigm [11] is associated with a decrease in PKC $\delta$ degradation [27], we determined if curcumin, administered in vivo, would similarly increase NCAM polysialylation state in the infragranular zone of the dentate gyrus of adult rats (postnatal day 80 ). Following daily administration of curcumin $(75 \mathrm{mg} / \mathrm{kg}$ by gavage) for an 8-day period, we counted a two-fold increase in polysialylated dentate neurons $(P<0.05$, Student's two-tailed $t$-test) (Figure 5B). Moreover, the arborisation of these polysialylated neurons in the upper granule cell layers and inner molecular layer was substantially increased, suggesting curcumin induced a substantial remodelling of the dentate neuronal architecture (Figure 5A). 
Curcumin-induced change in dentate NCAM polysialylation state also correlated with improved acquisition and consolidation of the water maze spatial learning paradigm in cohorts of both adult (postnatal day 80) and aged (postnatal day 540) Wistar rats. Adult animals treated with curcumin exhibited a significant difference in task acquisition over 4 sessions $(\mathrm{F}[1,72]=4.34, P=0.041$; twoway repeated measure ANOVA), as compared to the vehicle-treated controls (Figure 6A). These animals also spent significantly more time in the target quadrant during subsequent probe trials $(\mathrm{F}[1,72]=3.9 ; P=0.05$; two-way repeated measure ANOVA $)$ and this became significant at the 72 h recall time (Figure 6B), as judged by Bonferroni post-test and Mann-Whitney $U$-test $(P<0.05)$. These results demonstrated curcumin treatment to exert a marked improvement on both the acquisition and consolidation of the spatial learning task. Curcumin treatment also resulted in significant improvements in both acquisition and consolidation of the water maze task in the cohort of aged animals. Drug-treated animals exhibited a superior performance to their vehicletreated controls in task acquisition when assessed over 4 training sessions $(\mathrm{F}[1,40]=6.7 ; P=0.01$; two-way repeated measure ANOVA) (Figure 6C). Moreover, curcumin-treatment produced a most significant effect on task recall when measured at both the 24 and $72 \mathrm{~h}$ probe trials (Figure $6 \mathrm{D})$, as judged by a two-way repeated measure ANOVA $(\mathrm{F}[1,44]=8.2 ; P=0.006 ;)$ and Bonferroni post-test and Mann-Whitney $U$-test $(P<0.05)$. 


\section{DISCUSSION}

These studies have demonstrated increased $\mathrm{PKC} \delta$ degradation by curcumin to be associated with an enhanced expression of NCAM polysialylation state in mouse neuro-2A neuroblastoma cells. The ability of curcumin to suppress $\mathrm{PKC} \delta$ expression is consistent with our previous in vitro observations demonstrating phorbol activation and/or staurosporine inhibition of PKC $\delta$ to, respectively, suppress and/or enhance PST activity with the direct consequence of regulating the extent to which NCAM is glycosylated with extended chains of $\alpha 2,8$-polysialic acid [21]. The mechanism by which curcumin induces degradation of $\mathrm{PKC} \delta$ appears to be associated with increased phosphorylation of the $\mathrm{Tyr}^{311}$ residue which lies within the hinge region between the regulatory and catalytic domains of the enzyme. This finding agrees with previous studies which have demonstrated phosphorylation of the $\mathrm{Tyr}^{311}$ residue to first activate $\mathrm{PKC} \delta$ and subsequently render it more susceptible to degradation [34] when the hinge region becomes accessible to proteolytic cleavage during the conformational changes associated with enzyme activation [33]. Activation of PKC $\delta$ by phorbol esters is also known to trigger their ubiquitination and degradation [43]. Moreover, the $\operatorname{Tyr}^{311}$ residue of PKC $\delta$ is flanked by a sequence that forms an optimal binding substrate for the Src family of kinases that constitutively complex with PKC $\delta$ but not other PKC isoforms, such as PKC $\alpha$ or PKCE [44].

Chronic administration of curcumin in vivo was also demonstrated to enhance the polysialylation of neurons in the infragranular zone of the dentate gyrus and this included their dendritic tree which extends into the inner third of the molecular layer. $\alpha$-Tocopherol, which also reduces PKC $\delta$ expression [45], has been found to similarly enhance the polysialylation of neurons in the 
adult dentate gyrus and, moreover, generate greater complexity in their dendritic arbor, as evidenced by increased synaptophysin expression and synapse density in the molecular layer [46]. Upregulation of dentate NCAM PSA may also, in part, provide a basis for the neuroprotective actions attributed to curcumin [47] as chronic exposure to deprenyl, purported to slow nigral cell degeneration in Parkinson's disease [48], has been demonstrated to increase the frequency of dentate polysialylated cells [49]. Moreover, hyperthermia-induced upregulation of NCAM PSA appears to similarly protect against kainate-induced cell death [50]. Curcumin has been demonstrated to significantly increase the number of newly generated cells in the dentate infragranular zone [51], however, not all of these are polysialylated [52]. The ability of curcumin to enhance neuronal polysialylation through suppression of $\mathrm{PKC} \delta$ activity may more likely relate to the integration of newborn cells into the dentate neuronal architecture over the 1-2 month period that follows their birth [53], [54] and [55]. This mechanism would be consistent with the transient decrease in PKC $\delta$ expression and associated increase in dentate polysialylated cell frequency that is observed at the $12 \mathrm{~h}$ post-training time following avoidance conditioning [11], [27] and with other studies that have failed to implicate increased NCAM PSA-mediated plasticity with neurogenesis [11], [56], [17] and [50].

Chronic administration of curcumin to adult Wistar rats significantly improved their performance in both the acquisition and consolidation of the water maze spatial learning paradigm. This is not surprising given that chronic administration of curcumin produces a two-fold increase in the frequency of polysialylated dentate neurons, the numerical density of which may be directly correlated to improvement in task performance [57] and [49]. Environmental enrichment, for example, robustly improves spatial learning and memory and is associated with increased NCAM 
polysialylation [58] and [49] and also a decreased expression of PKC $\delta$ [27]. Moreover, a pyrazole analogue of curcumin [59] has been demonstrated to facilitate the induction of LTP and performance in an object recognition paradigm in Wistar rats through the induction of $\mathrm{Ca}^{++} /$calmodulin-dependent protein kinase II [60], a mechanism known to be necessary for both spatial learning and NCAM-mediated neuroplasticity [61] and [62]. Although, the dose of curcumin required to enhance NCAM polysialylation and cognition in vivo was relatively high $(75 \mathrm{mg} / \mathrm{kg}$ ), no effect on either parameter was found at a dose of $37.5 \mathrm{mg} / \mathrm{kg}$ (data not shown), it was within the range previously reported necessary to induce neuroprotective effects in vivo [63] and [64]. Moreover, the dose at which curcumin mediates these neuroplastic actions is likely to be exceptionally low as its bioavailability is exceedingly poor, the majority being excreted in the feces, and only small fraction of the dose penetrates the brain, estimated to be approximately $0.3 \%$ of the administered dose in mice [65] and [47]. The lack of any behavioural toxicity in these studies, and those of others in both animals and humans [66] and [67], further implies the effective dose of curcumin necessary to enhance NCAM PSA expression and cognition to be exceptionally small. This unique action of curcumin may have significant implications in facilitating memory formation as the extent of PSA activation is commensurate with the difficulty experienced with task consolidation [57].

Curcumin also significantly improved spatial learning ability in aged animals despite the significant age-dependent decrease in NCAM polysialylation state [28] and increase in PKC $\delta$ expression [27]. However, extensive NCAM polysialylation is not necessary for the acquisition and/or consolidation of behavioural paradigms in aged animals [68] and [18] and appears to relate mainly to the graded, experience-expectant development of explicit memory systems that 
continue to evolve into maturity [69]. Curcumin can also regulate the in vivo expression of several other cell signaling systems required for neuroplastic events necessary for memory formation, notably Notch-1 and NFKB [70], [71], [72], [73] and [74]. Nevertheless, facilitation of PSA activation by curcumin, however minimal, may have implications for the treatment of neurodegenerative conditions. In Alzheimer's disease, the natural autoprotective response to agerelated cognitive deficits is a small, but significant, activation of dentate polysialylated cell frequency [75] and, over the past few years, an increasing number of studies have highlighted the therapeutic potential of curcumin for the treatment of this condition [76] and [77], a suggestion further supported by its ability to reduce $\beta$-amyloid plaque burden in animal models [78]. Moreover, human populations exposed to curcumin show significantly reduced incidence of Alzheimer's disease, but not ApOE polymorphisms [79], and improved cognitive ability as compared to a control group [80]. 


\section{REFERENCES}

[1] R. Sadoul, M. Hirn, H. Deagostini-Bazin, G. Rougon and C. Goridis, Adult and embryonic mouse neural cell adhesion molecules have different binding properties, Nature 30 (1983), pp. 347-349.

[2] G. Rougon, C. Dubois, N. Buckley, J.L. Magnani and W. Zollinger, A monoclonal antibody against meningococcus group B polysaccharides distinguishes embryonic from adult N-CAM, $J$ Cell Biol 103 (1986), pp. 429-437.

[3] L. Bonfanti, PSA-NCAM in mammalian structural plasticity and neurogenesis, Prog. Neurobiol 80 (2006), pp. 129-164.

[4] E. Gascon, L. Vutskits and J.Z. Kiss, Polysialic acid-neural cell adhesion molecule in brain plasticity: From synapses to integration of new neurons, Brain Res Rev 56 (2007), pp. 101-118.

[5] U. Rutishauser, Polysialic acid in the plasticity of the developing and adult vertebrate nervous system, Nat. Rev. Neurosci. 9 (2008), pp. 26-35.

[6] Z.S. Hoyk, A. Parducz and D.T. Theodosis, The highly sialylated isoform of the neural cell adhesion molecule is required for estradiol-induced morphological plasticity in the adult arcuate nucleus, Eur J Neurosci 13 (2001), pp. 649-656. 
[7] L. Stoenica, O. Senkov, R. Gerardy-Schahn, B. Weinhold, M. Schachner and A. Dityatev, In vivo synaptic plasticity in the dentate gyrus of mice deficient in the neural cell adhesion molecule NCAM or its polysialic acid, Eur J Neurosci 23 (2006), pp. 2255-2264.

[8] A. O’Malley, C. O’Connell and C.M. Regan, Ultrastructural analysis reveals avoidance conditioning to induce a transient increase in hippocampal dentate spine density in the $6 \mathrm{~h}$ posttraining period of consolidation, Neuroscience 87 (1998), pp. 607-613.

[9] A. O’Malley, C. O’Connell, K.J. Murphy and C.M. Regan, Transient spine density increases in the mid-molecular layer of the hippocampal dentate gyrus accompany consolidation of a spatial learning task in the rodent. Neuroscience 99 (2000), pp. 229-232.

[10] M.D. Eyre, G. Richter-Levin, A. Avital and M.G. Stewart, Morphological changes in the hippocampal dentate gyrus synapses following spatial learning in rats are transient. European $J$ Neurosci 17 (2003), pp. 1973-80

[11] G.B. Fox, A.W. O'Connell, K.J. Murphy and C.M. Regan, Memory consolidation induces a transient and time-dependent increase in the frequency of NCAM-polysialylated cells in the adult rat hippocampus, $J$ Neurochem 65 (1995), pp. 2796-2779.

[12] K.J. Murphy, A.W. O' Connell and C.M. Regan, Repetitive and transient increases in hippocampal neural cell adhesion molecule polysialylation state following multi-trial spatial training, J Neurochem 67 (1996), pp. 1268-1274. 
[13] C. Sandi, J.J. Merino, M.I. Cordero, N. Kruyt, K.J. Murphy and C.M. Regan, Modulation of hippocampal NCAM polysialylation by stressful experiences, Biol Psychiat 15 (2003), pp. 599607.

[14] C.G. Becker, A. Artola, R. Gerardy-Schahn, T. Becker, H. Welzl and M. Schachner, The polysialic acid modification of the neural cell adhesion molecule is involved in spatial learning and hippocampal long-term potentiation, J Neurosci Res 45 (1996), pp. 143-152.

[15] D. Muller, C. Wang, G. Skibo, N. Toni, H. Cremer, V. Calaora et al., PSA-NCAM is required for activity-induced synaptic plasticity, Neuron 17 (1996), pp. 413-422.

[16] C. Venero, A.I. Herrero, K. Touyarot, K. Cambon, M.A. López-Fernández, V. Berezin et al., Hippocampal up-regulation of NCAM expression and polysialylation plays a key role on spatial memory, Eur J Neurosci 23 (2006), pp. 1585-95.

[17] M.A. Lópéz-Fernández, M.-F. Montaron, E. Varea, G. Rougon, C. Venero, D.N. Abrous et $a l .$, Upregulation of polysialylated neural cell adhesion molecule in dorsal hippocampus after contextual fear conditioning is involved in long-term memory formation, $J$ Neurosci 27 (2007), pp. $4552-4561$.

[18] C.M. Seymour, A.G. Foley, K.J. Murphy and C.M. Regan, Intraventricular infusions of antiNCAM PSA impair the process of consolidation of both avoidance conditioning and spatial learning paradigms in Wistar rats, Neuroscience (2008), In Press. 
[19] E.P. Scheidegger, L.R. Sternberg, J. Roth and J.B. Lowe, A human STX cDNA confers polysialic acid expression in mammalian cells, J Biol Chem 270 (1995), pp. 22685-22688

[20] Y. Yoshida, N. Kojima, N. Kurosawa, T. Hamamoto and S. Tsuji, Molecular cloning of Sia alpha 2,3Gal beta 1,4GlcNAc alpha 2,8-sialyltransferase from mouse brain, $J$ Biol Chem 270 (1995), pp. 14628-14633.

[21] M. Eckhardt, M. Mühlenhoff, A. Bethe, J. Koopman, M. Frosch and R. Gerardy-Schahn, Molecular characterization of eukaryotic polysialyltransferase-1, Nature 373 (1995), pp. 715-718.

[22] J. Nakayama, M.N. Fukuda, B. Fredette, B. Ranscht and M. Fukuda, Expression cloning of a human polysialyltransferase that forms the polysialylated neural cell adhesion molecule present in embryonic brain, Proc Natl Acad Sci USA 92 (1995), pp. 7031-7035.

[23] H. Hildebrandt, C. Becker, M. Murau, R. Gerardy-Schahn and H. Rahmann, Heterogenous expression of the polysialyltransferases ST8Sia II and ST8Sia IV during postnatal rat brain development, J Neurochem 71 (1998), pp. 2339-2348.

[24] E. Ong, J. Nakayama, K. Angata, L. Reyes, T. Katsuyama, Y. Arai and M. Fukuda, Developmental regulation of polysialic acid synthesis in mouse directed by two polysialyltransferases, PST and STX, Glycobiology 8 (1998), pp. 415-424. 
[25] G. Alcaraz and G. Goridis, Biosynthesis and processing of polysialylated NCAM by AtT20 cells. Eur J Cell Biol 55 (1991), pp. 165-173.

[26] H.C. Gallagher, O.A. Odumeru and C.M. Regan CM, Regulation of neural cell adhesion molecule polysialylation state by cell-cell contact and protein kinase C delta, J Neurosci Res $\mathbf{6 1}$ (2000), pp. 636-645.

[27] H.C. Gallagher, K.J. Murphy, A.G. Foley and C.M. Regan, Protein kinase C delta regulates neural cell adhesion molecule polysialylation state in the rat brain, J Neurochem 77 (2001), pp. 425-34.

[28] G.B. Fox, N. Kennedy, and C.M. Regan, Polysialylated neural cell adhesion molecule expression by neurons and astroglila processes in the rat dentate gyrus declines dramatically with increasing age, Int J Dev Neurosci 13 (1995), pp. 663-72.

[29] X. Gu, U. Preuß, T. Gu and R.K. Yu, Regulation of sialyltransferase activities by phosphorylation and dephosphorylation, J Neurochem 64 (1995), pp. 2295-2302.

[30] L. Gao, X.-B. Gu, D.S. Yu, R.K. Yu and G. Zeng, Association of a 14-3-3 protein with CMP-NeuNAc: GM1 a2,3-sialyltransferase, Biochem Biophys Res Commun 224 (1996), pp. 103-107. 
[31] J. Ma, M. Siminovic, R. Qian and K.J. Colley, Sialyltransferase isoforms are phosphorylated in the cis-medial Golgi on serine and threonine residues in their luminal sequences. $J$ Biol Chem 274 (1999), pp. 8046-8052.

[32] K.C. Breen and N. Georgopoulou, The role of protein phosphorylation in $\alpha 2,6(N)$ sialyltransferase activity, Biochem Biophys Res Comm 309 (2003), pp. 32-35.

[33] A. Kishimoto, K. Mikawa, K. Hashimoto, I. Yasuda, S. Tanaka, M. Tominaga et al., Limited proteolysis of protein kinase $\mathrm{C}$ subspecies by calcium-dependent neutral protease (calpain), $J$ Biol Chem 264 (1989), pp. 4088-4092.

[34] R.A. Blake, P. Garcia-Paramio, P.J. Parkera and S.A. Courtneidge Src promotes PKC $\delta$ degradation, Cell Growth Diff 10 (1999), pp. 231-241.

[35] M. Gschwendt, H.J. Muller, K. Kielbassa, R. Zang, W. Kittstein, G. Rincke et al., Rottlerin, a novel protein kinase inhibitor, Biochem Biophys Res Commun 199 (1994), pp. 93-98.

[36] S.P. Davies, H. Reddy, M. Caivano and P. Cohen, Specificity and mechanism of action of some commonly used protein kinase inhibitors, Biochem J 351 (2000), pp. 95-105.

[37] S.P. Soltoff, Rottlerin: an inappropriate and ineffective inhibitor of PKC $\delta$, Trends Pharmacol Sci 28 (2007), pp. 453-458. 
[38] C.A. Lipinski, F. Lombardo, B.W. Dominy and F.P. Feeney, Experimental and computational approaches to estimate solubility and permeability in drug discovery and development settings, Adv Drug Deliv Rev 23 (1997), pp. 3-25.

[39] K. Godl, J. Wissing, A. Kurtenbach, P. Habenberger, S. Blencke, H. Gutbrod et al., An efficient proteomics method to identify the cellular targets of protein kinase inhibitors, Proc Natl Acad Sci USA 100 (2003), pp. 15434-15439.

[40] G. Zhang, M.G. Kazanietz, P.M. Blumberg and J.H. Hurley, Crystal structure of the cys2 activator-binding domain of protein kinase C delta in complex with phorbol ester, Cell $\mathbf{8 1}$ (1995) pp. 917-924.

[41] Y.J. Wang, M.H. Pan, A.L. Cheng, L.I. Lin, Y.S. Ho, C.Y. Hsieh et al., Stability of curcumin in buffer solutions and characterization of its degradation products. J Pharm Biomed Anal 15 (1997), pp. 1867-1876.

[42] K. Mizuno, T.C. Saido, S. Ohno, T. Tamaoki and K. Suzuki, Staurosporine-related compounds, K252a and UCN-01, inhibit both cPKC and nPKC, FEBS Lett 330 (1993), pp. 114 116.

[43] Z. Lu, D. Liu, A. Hornia, W. Devonish, M. Pagano and D.A. Foster, Activation of protein kinase C triggers its ubiquitination and degradation, Mol Cell Biol 18 (1998), pp. 839-845. 
[44] S.F. Steinberg, Distinctive activation mechanisms and functions for protein kinase Cdelta, Biochem J 384 (2004), pp. 449-459.

J.M. Zingg and A. Azzi, Non-antioxidant activities of vitamin E, Curr Med Chem 11 (2004), pp. 1113-1133.

[45] P. Ferri, T. Cecchini, P. Ambrogini, M. Betti, R. Cuppini, P. Del Grande et al., $\alpha$ Tocopherol affects neuronal plasticity in adult rat dentate gyrus: The possible role of PKC $\delta . J$ Neurobiol 66 (2006), pp. 793-810.

[46] A. Goel, A.B. Kunnumakkara and B.B. Aggarwal, Curcumin as "Curecumin": From kitchen to clinic, Biochem Pharmacol 75 (2008), pp. 787-809.

[47] M. Ebadi, S. Sharma, S. Shavali and H. El Reaey, Neuroprotective actions of selegiline, $J$ Neurosci Res 67 (2002), pp. 285-289.

[48] K.J. Murphy, A.G. Foley, A.W. O'Connell and C.M. Regan, Chronic exposure of rats to cognition enhancing drugs produces a neuroplastic response identical to that obtained by complex environment rearing, Neuropsychopharmacology 31 (2006), pp. 90-100.

[49] V. Duveau, S. Arthaud, A. Rougier and G. Le Gal le Salle, Polysialylation of NCAM is upregulated by hyperthermia and participates in heat shock preconditioning-induced neuroprotection, Neurobiol Disease 26 (2007), pp. 385-395. 
[50] S.J. Kim, T.G. Son, H.R. Park, M. Park, M.S. Kim, H.S. Kim et al., Curcumin stimulates proliferation of embryonic neural progenitor cells and neurogenesis in the adult hippocampus, $J$ Biol Chem 283, pp. 14497-14505.

[51] A.G. Foley, W.D. Hirst, H.G. Gallagher, C. Barry, J.J. Hagan, N. Upton, A.J. Hunter, F.S. Walsh and C.M. Regan, The selective 5-HT 6 receptor antagonists SB-271046 and SB-399885 potentiate NCAM-PSA immunolabelling of dentate granule cells, but not neurogenesis, in the hippocampal formation of mature Wistar rats, Neuropharmacology 54 (2008), pp. 1166-1174.

[53] S. Ge, C.H. Yang, K.S. Hsu, G.L. Ming and H. Song, A critical period for enhanced synaptic plasticity in newly generated neurons of the adult brain. Neuron 54 (2007), pp. 559-566.

[54] N. Kee, C.M. Teixeira, A.H. Wang, and P.W. Frankland, Preferential incorporation of adultgenerated granule cells into spatial memory networks in the dentate gyrus, Nat Neurosci $\mathbf{1 0}$ (2007), pp. 355-362.

[55] N. Toni, D.A. Laplagne, C. Zhao, G. Lombardi, C.E. Ribak, F.H. Gage et al., Neurons born in the adult dentate gyrus form functional synapses with target cells, Nature Neurosci 11 (2008), pp. 901-907.

[56] K. Pham, B.S. McEwen, J.E. LeDoux and K. Nader, Fear learning transiently impairs hippocampal cell proliferation, Neuroscience 130 (2005), pp. 17-24. 
[57] C. Sandi, M.I. Cordero, J.J. Merino, N.D. Kruyt, C.M. Regan and K.J. Murphy, Neurobiological correlates of individual differences in spatial learning ability, Learn Mem $\mathbf{1 1}$ (2004), pp. 244-252.

[58] D. Young, P.A. Lawlor, P. Leone, M. Dragunow and M.J. During, Environmental enrichment inhibits spontaneous apoptosis, prevents seizures and is neuroprotective. Nature Med 5 (1999), pp. 448-453.

[59] Y. Liu, R. Dargusch, P. Maher, and D. Schubert, A broadly protective derivative of curcumin, J Neurochem 105 (2008), pp. 1336-1345.

[60] P. Maher, T. Akaishi, D. Schubert, and K. Abe, A pyrazole derivative of curcumin enhances memory, Neurobiol Aging (2008), In Press.

[61] A.J. Silva, R. Paylor, J.M. Wehner, S. Tonegawa, Impaired spatial learning in alphacalcium-calmodulin kinase II mutant mice, Science 257 (1992), pp. 206-211

[62] E.J. Williams, B. Mittal, F.S. Walsh, and P. Doherty, A Ca2+/calmodulin kinase inhibitor, KN-62, inhibits neurite outgrowth stimulated by CAMs and FGF, Mol Cell Neurosci 6 (1995), pp. 69-79. 
[63] B. Jagatha, R.B. Mythri, S. Vali and M.M.S. Bharath, Curcumin treatment alleviates the effects of glutathione depletion in vitro and in vivo: Therapeutic implications for Parkinson's disease explained via in silico studies, Free Radic Biol Med 44 (2008), 907-917.

[64] P.K. Shukla, V.K. Khanna, M.M. Ali, M.Y. Khan and R.C. Srimal, Anti-ischemic effect of curcumin in rat brain, Neurochem Res 33 (2008), pp. 1036-1043.

[65] E.K. Ryu, Y.S. Choe, K.H. Lee, Y. Choi and B.T. Kim, Curcumin and dihydrozingerone derivatives: synthesis, radiolabelling, and evaluation for beta-amyloid plaque imaging, $J M e d$ Chem 49 (2006), pp. 6111-6119.

[66] T.N. Shankar, N.V. Shanta, H.P. Ramesh, I.A. Murthy and V.S. Murthy, Toxicity studies on tumeric (Curcuma longa): acute toxicity studies in rats, guineapigs and monkeys, Indian J Exp Biol 18 (1980), pp. 73-75.

[67] C.D. Lao, M.T. Ruffin, D. Normolle, D.D. Heath, S.I. Murray, J.M. Bailey et al., Dose escalation of a curcuminoid formulation, BMC Complement Altern Med 6 (2006), pp. 10.

[68] D. N. Abrous, M.F. Montaron, K.G. Petry, G. Rougon, M. Darnaudery, M. Le Moal et al., Decrease in highly polysialylated neuronal cell adhesion molecules and in spatial learning during ageing are not correlated, Brain Res 744 (1997), pp. 285-292. 
[69] M.E. Stanton, Multiple memory systems, development and conditioning, Behav Brain Res 110 (2000), pp. 25-37.

[70] A Romano, R. Freudenthal, E. Merlo, and A. Routtenberg, Evolutionarily-conserved role of the NF-kappaB transcription factor in neural plasticity and memory, Eur J Neurosci 24 (2006), pp. 1507-1516.

[71] Y. Wang, S.L. Chan, L. Miele, P.J. Yao, J. Mackes, D.K. Ingram et al., Involvement of Notch signalling in hippocampal plasticity, Proc Natl Acad Sci. USA 101 (2004), pp. 9458-9462.

[72] Y. Chen, W. Shu, W. Chen, Q. Wu, H. Liu and G. Cui, Curcumin, both Histone Deacetylase and p300/CBP-Specific Inhibitor, Represses the Activity of Nuclear Factor Kappa B and Notch 1 in Raji Cells, Basic Clin Pharmacol Toxicol 101 (2007), pp. 427-433.

[73] L. Conboy, C.M. Seymour, M.P. Monopoli, N.C. O'Sullivan, K.J. Murphy and C.M. Regan, Notch signalling becomes transiently attenuated during long-term memory consolidation in adult Wistar rats, Neurobiol Learn Mem 88 (2007) pp. 342-351.

[74] S. Shishodia, T. Singh and M.M. Chaturvedi, Modulation of transcription factors by curcumin, Adv Exp Med Biol 595 (2007), pp. 127-148. 
[75] M. Mikkonen, H. Soininen, T. Tapiola, I. Alafuzoff and R. Miettinen, Hippocampal plasticity in Alzheimer's disease: changes in highly polysialylated NCAM immunoreactivity in the hippocampal formation, Eur J Neurosci 11 (1999), pp. 1754-1764.

[76] A. Wu, Z. Ying and F. Gomez-Pinilla, Dietary curcumin counteracts the outcome of traumatic brain injury on oxidative stress, synaptic plasticity, and cognition, Exp Neurol 197 (2006), pp. 309-317.

[77] Y. Xu, B. Ku, L. Tie, H. Yao, W. Jiang, X. Ma and X. Li, Curcumin reverses the effects of chronic stress on behaviour, the HPA axis, BDNF expression and phosphorylation of CREB, Brain Res 1122 (2006), pp. 56-64.

[78] A. N. Begum, M.R. Jones, G.P. Lim, T. Morihara, P. Kim, D.D. Heath et al., Curcumin structure-function, bioavailability, and efficacy in models of neuroinflammation and Alzheimer's disease, J Pharmacol Exp Ther 326 (2008), pp. 196-208.

[79] M. Ganguli, V. Chandra, M.I. Kamboh, J.M. Johnston, H.H. Dodge, B.H. Thelma et al., Apolipoprotein E polymorphism and Alzheimer disease, Arch Neurol 57 (2000), pp. 824-830.

[80] T.P. Ng, P.C. Chiam, T. Lee, H.C. Chua, L. Lim, and E.H. Kua, Curry consumption and cognitive function in the elderly, Am J Epidemiol 164 (2006), pp. 898-906. 
1

2

\section{ACKNOWLEDGEMENTS}

We would like to thank Suzanne Prenter for technical assistance. This work was supported by Enterprise Ireland. 


\section{FIGURE LEGENDS}

Figure 1: In silico approach to identification of curcumin as a rottlerin analogue.

The chemical structure of rottlerin and curcumin with the pharmacopore side chain in bold is shown in Panel A. Crystal structure of the PKC $\delta$ CIB binding site is shown in Figure 1Bi along with its interaction with the phorbol ester (Figure 1Bii) and curcumin (Figure 1Biii). Figure 1C shows a histogram plot of the 137 rottlerin-like molecules and their strength of their interaction, based on dock score, with the $\mathrm{PKC} \delta \mathrm{C} 1 \mathrm{~B}$ domain (Figure 1C). Figure 1D demonstrates the curcumin-induced, dose-dependent increase in PSA expression in neuro-2A neuroblastoma cells.

Figure 2: Influence of curcumin and rottlerin on recombinant $\mathrm{PKC} \delta$ activity. Panel A illustrates the purity of the enzyme preparation (lane 1: enzyme preparation; lane 2: molecular weight markers) and Panel B shows enzyme activity with increasing concentrations of recombinant PKC $\delta$. Panel $\mathrm{C}$ demonstrates inhibition of enzyme activity, in the presence of $40 \mu \mathrm{M}$ (filled columns) and $200 \mu \mathrm{M}$ (open columns) ATP, using staurosporine as a positive control. This panel also shows rottlerin and curcumin to be without effect on PKC $\delta$ activity. The data is expressed as the mean $\pm \operatorname{SEM}(n=3)$ and values significantly different $(p<0.05)$ from the vehicle-treated controls are indicated with an asterisk.

Figure 3: Association of curcumin-conjugated Sepharose-6B with $\mathrm{PKC} \delta$ in lysates from the hippocampal dentate gyrus. Panel A shows the Coomassie blue-stained gel analysis of beadassociated protein (lanes 1 and 2) and the remaining lysate following bead incubation (lanes 4 
and 5). Lane 5 shows the protein profile of the lysate. All lanes had equal protein loading. Panel B shows the immunoblot analysis of the same lanes with anti-PKC $\delta$.

Figure 4: Influence of curcumin on PKC $\delta$ expression in neuro2A neuroblastoma cells. The immunoblot in Panel A illustrates a curcumin-induced, dose-dependent decrease in PKC $\delta$ enzyme protein and the histogram in Panel B shows the same data expressed in a semiquantitative densitometric manner. Equal protein loading is shown with the actin immunoblot in Panel A. Panel C shows the dose-dependent increase in PKC $\delta$ tyrosine ${ }^{311}$ phosphorylated PKC $\delta$ and its fragments in the presence of curcumin and Panel D is a semi-quantitative densitometric of the same data. All data is expressed as the mean $\pm \operatorname{SEM}(n=3)$ and values significantly different $(\mathrm{p}<0.05)$ from the vehicle-treated controls are indicated with an asterisk.

Figure 5: Influence of chronic curcumin administration on polysialylated cell frequency in the infragranular zone of the hippocampal dentate gyrus of the adult Wistar rat (postnatal day 80). Panel A and B form a qualitative comparison of dentate polysialylated cells (see arrow heads in Panel B) and Panel C represents their quantitative analysis. The animals received $75 \mathrm{mg} / \mathrm{kg}$ curcumin by gavage each day for 8 days. All data is expressed as the mean $\pm \operatorname{SEM}(n=3)$ and values significantly different $(\mathrm{p}<0.05)$ from the vehicle-treated controls are indicated with an asterisk.

Figure 6: Influence of chronic administration of curcumin on spatial learning in adult and aged Wistar rats. Panels A and B illustrate the influence of curcumin on acquisition and consolidation, respectively, of the water maze paradigm in adult animals. Task acquisition was carried out over 
four daily sessions of five trials and consolidation was assessed by determining recall at $24 \mathrm{~h}$ and $72 \mathrm{~h}$ following the last training session. Panels $\mathrm{C}$ and $\mathrm{D}$ illustrate the same data for the aged animal group. Both the adult ( $\mathrm{n}=10$ for both vehicle and curcumin groups) and aged ( $\mathrm{n}=7$ for vehicle group; $\mathrm{n}=5$ for the aged group) cohorts received $75 \mathrm{mg} / \mathrm{kg}$ curcumin by gavage each day for 8 days. Significant difference in task acquisition over 4 daily sessions was determined using a two-way repeated measure ANOVA with Bonferroni post hoc test and Mann-Whitney U-test employed to determine significance at the $24 \mathrm{~h}$ and $72 \mathrm{~h}$ recall times $(* P<0.05$ vs. vehicle). 
A<smiles>[R]O[R]O</smiles><smiles>[2H]OC(=C\C(=O)/C=C/c1ccc(O)c(OC)c1)/C=C/c1ccc(O)c(OC)c1</smiles>

C

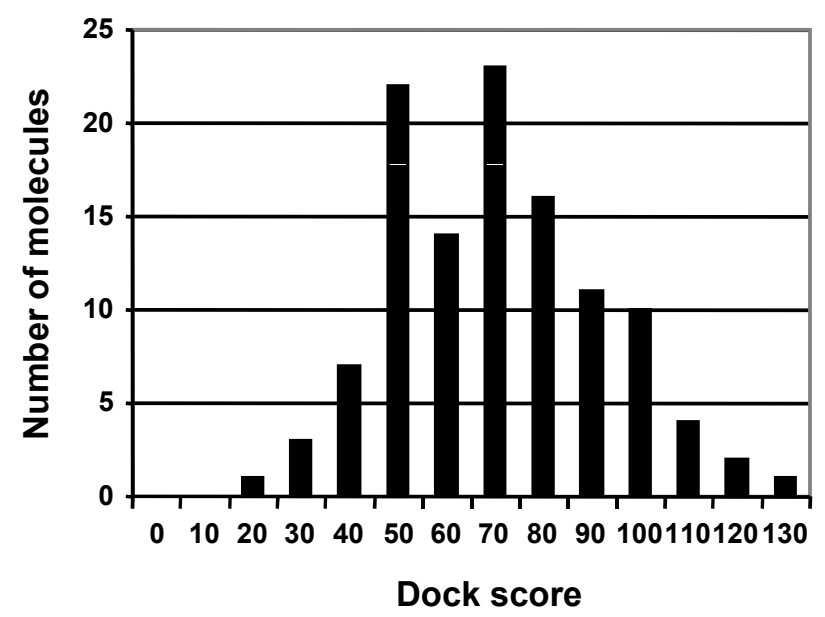

B
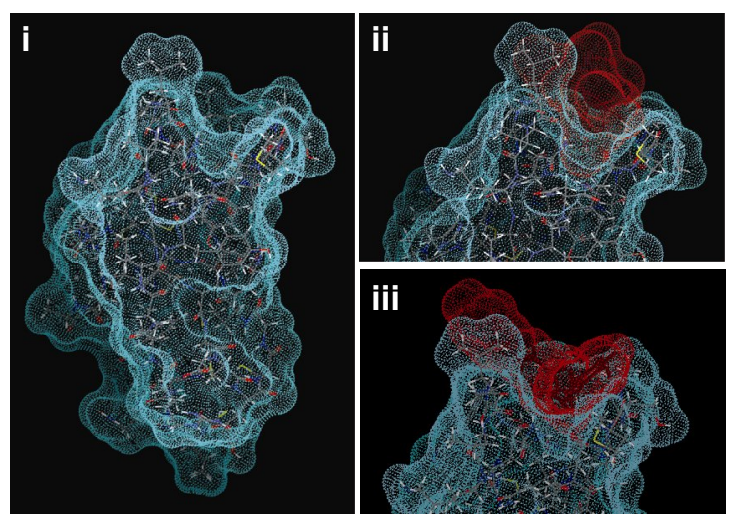

D

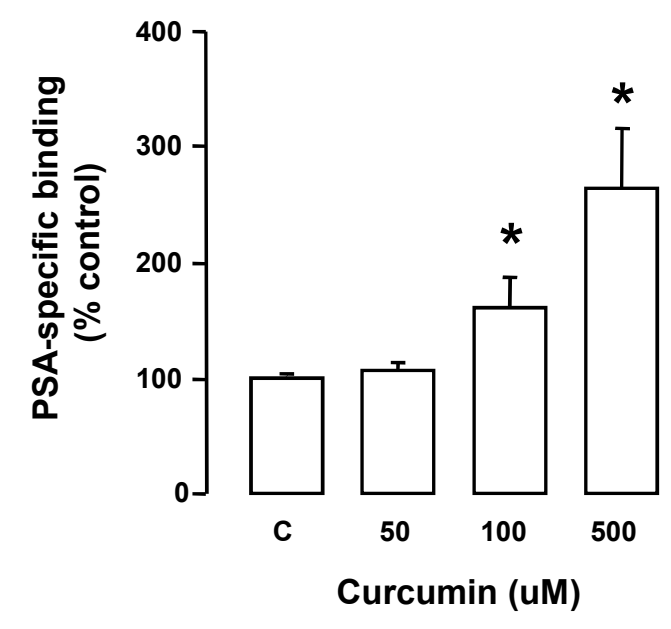

Figure 1; Conboy et al. 

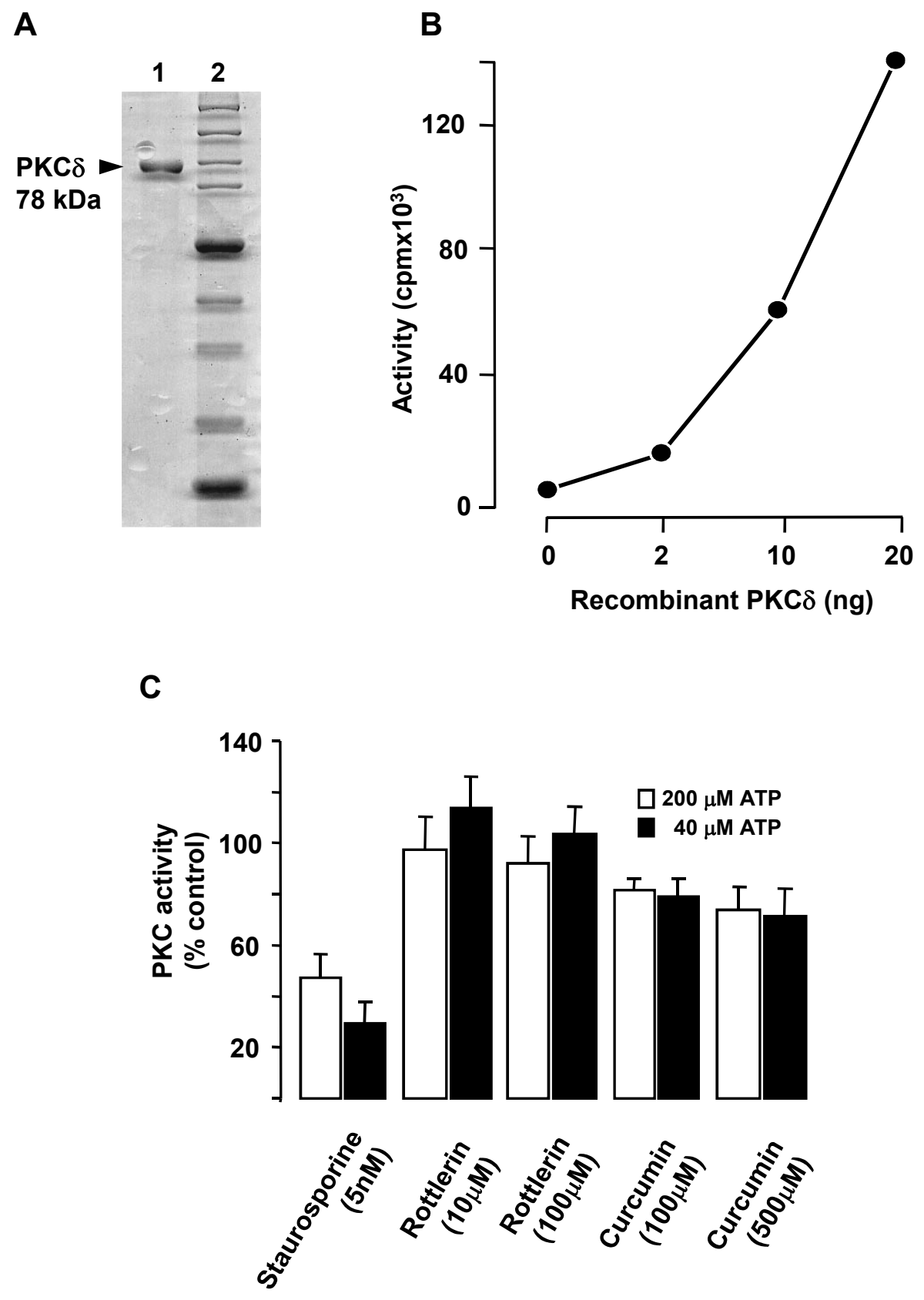

Figure 2; Conboy et al. 


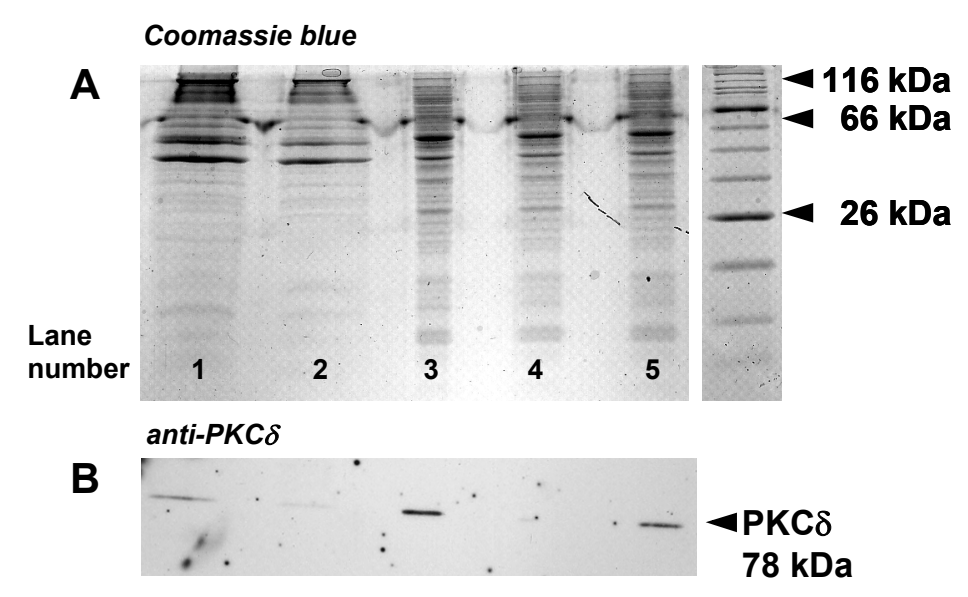

1: Curcumin-coupled Sepharose 6B

2: Sepharose 6B

3: Total lysate

4: Lysate post-curcumin-coupled Sepharose 6B

5: Lysate post-Sepharose 6B

Figure 3; Conboy et al. 
A

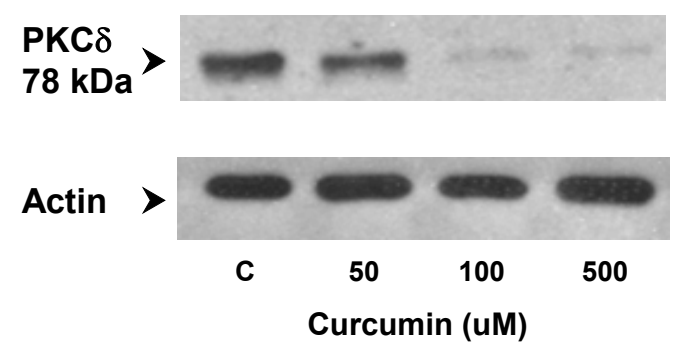

B

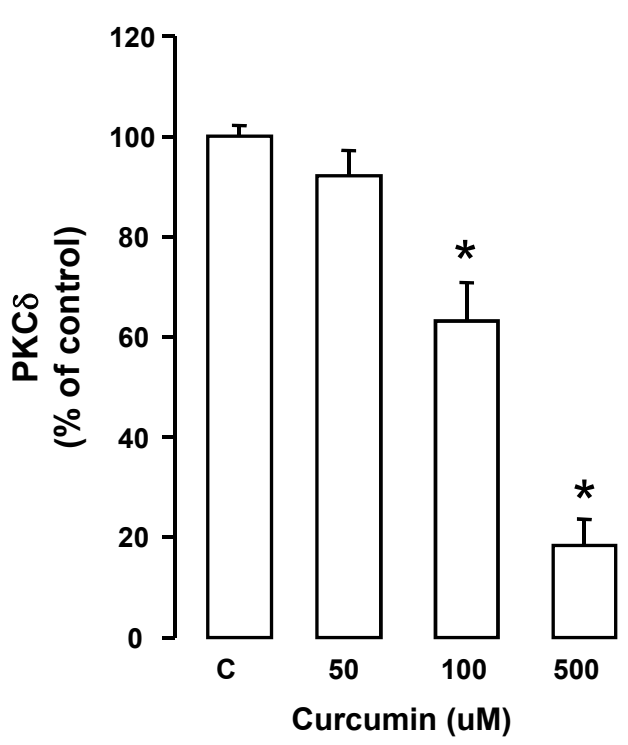

C $k \mathrm{ka}$

Phospho-PKC $\delta>$ (Tyr $\left.{ }^{311}\right)$

Phospho-PKC $\delta>$ (Tyr $\left.{ }^{311}\right)$ fragments

Curcumin (uM)

D

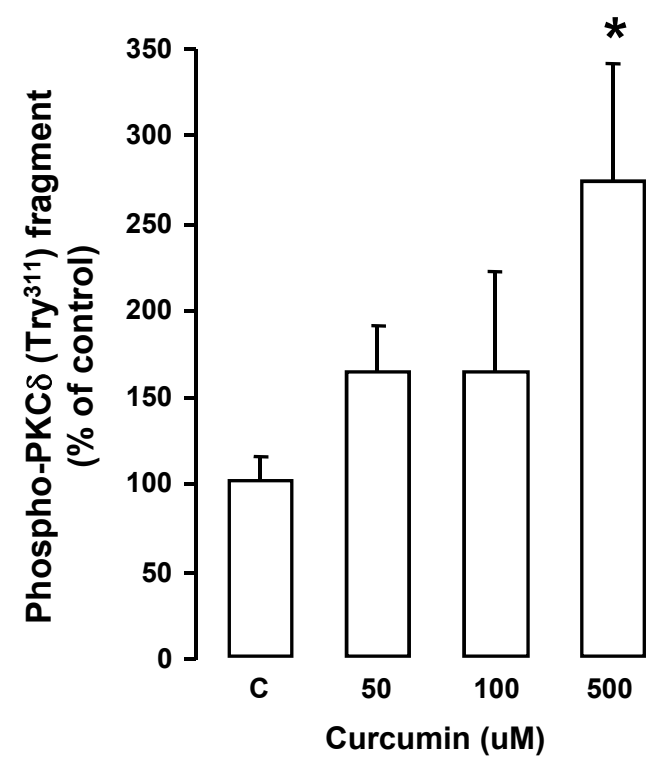

Figure 4; Conboy et al. 
A

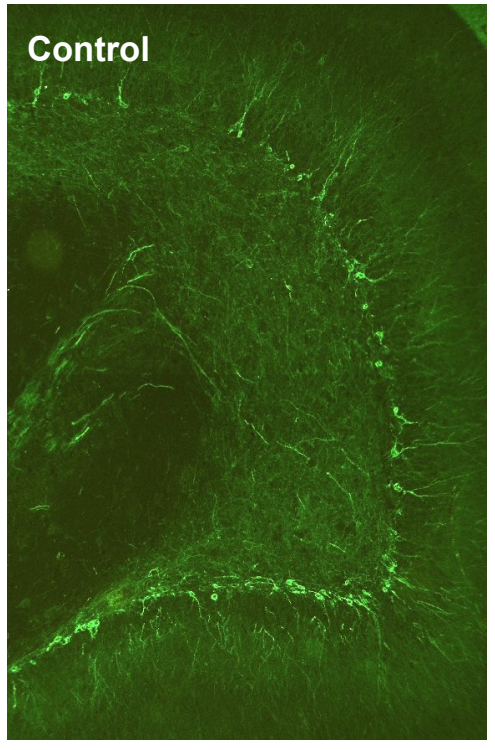

B

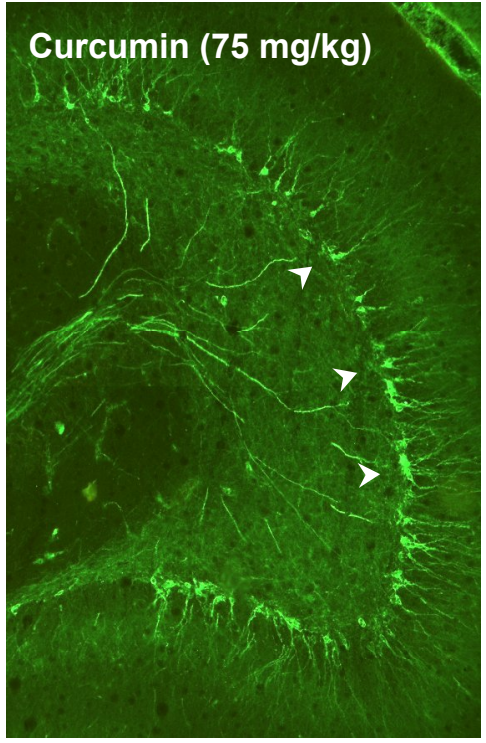

C

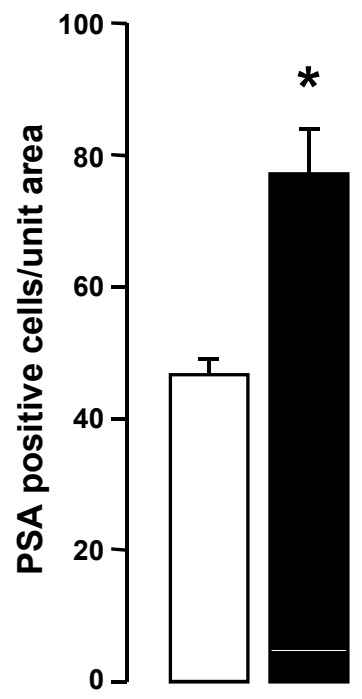

Figure 5; Conboy et al. 
A

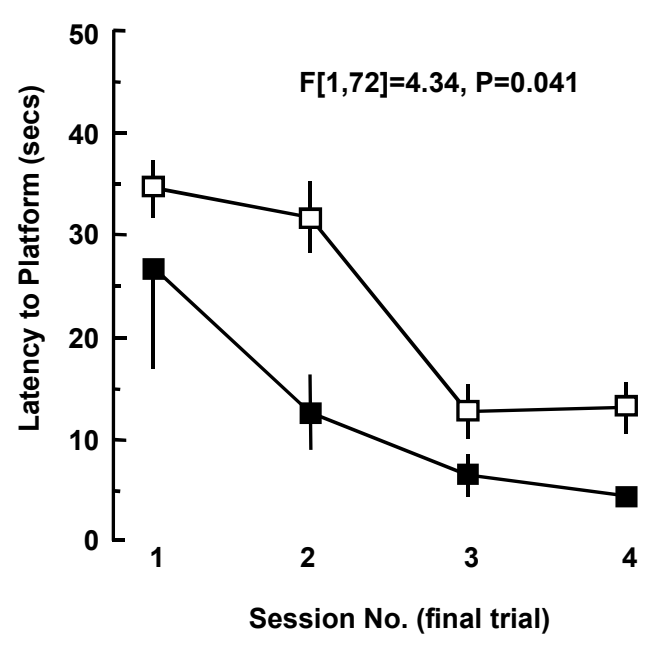

C

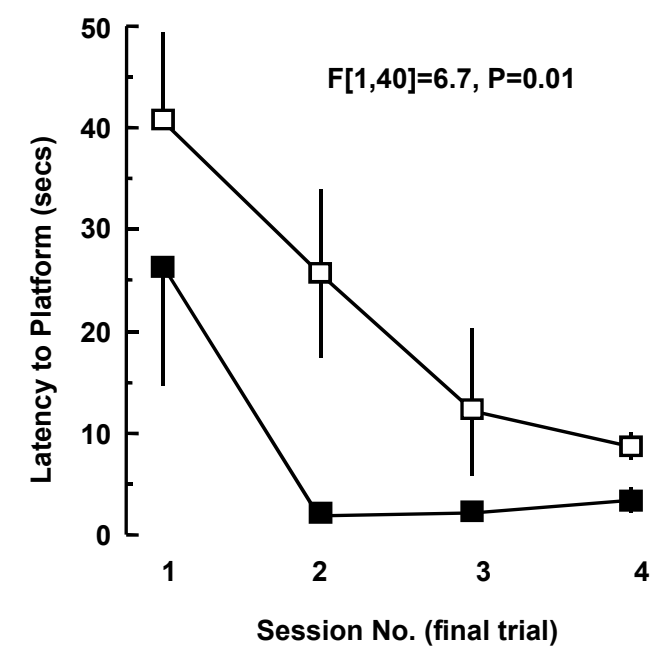

B

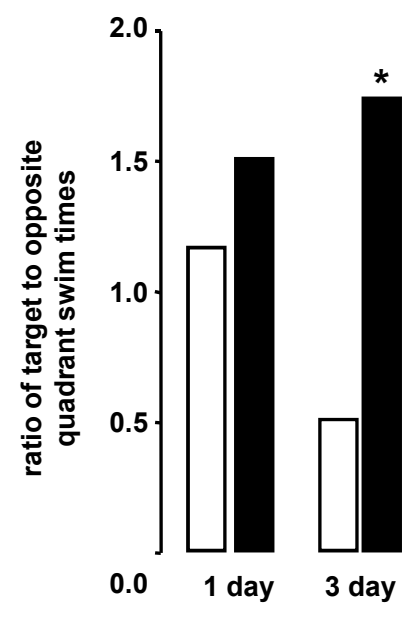

D

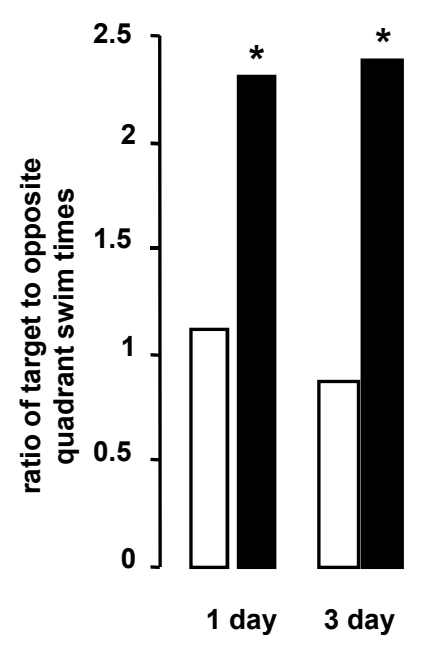

Figure 6; Conboy et al. 
Curcumin increases NCAM polysialylation state through degradation of the PKC $\delta$ inhibitor of polysialyltransferase and improves spatial learning in adult and aged Wistar rats.
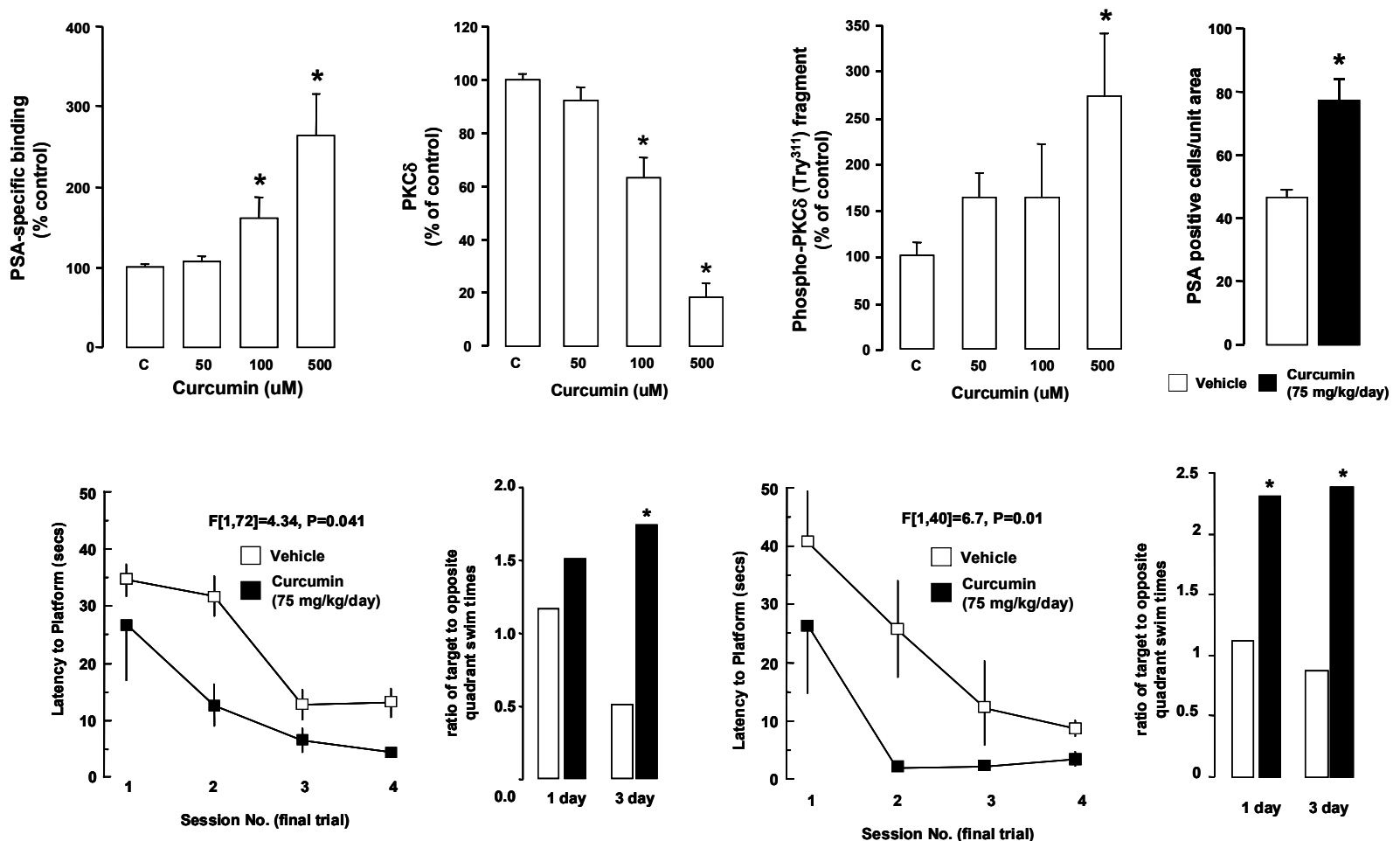